\title{
Redaksioneel
}

\section{Die bewaring van ons kusomgewing}

Dit word allerweë aanvaar dat Suid-Afrika 'n land van besondere skoonheid is - 'n land met 'n verstommende veelvuldigheid aan landskapsvorms, plante en diere, asook aan menslike gemeenskappe.

Hierdie veelvuldigheid word in Suid-Afrika se kusomgewing weerspieël. Hoeveel lande in die wêreld het $3000 \mathrm{~km}$ kuslyn wat deur drie oseane omspoel en beïnvloed word die Atlantiese, die Indiese en die Suidelike oseaan? Hoeveel lande se kuswaters wissel van warm subtropies soos langs ons ooskus, tot koud soos langs ons weskus wanneer opstuwing van ysige waters uit die dieptes van die Suidelike Oseaan plaasvind? Hoeveel lande is geseën met ryke, lewende hulpbronne soos ons hengelvisse, kreef, perlemoen en die pelagiese en diepwatersoorte wat selfs deur internasionale visseryvlote benut word, tot nielewende hulpbronne soos diamante, gas, olie en swaar metale? En watter land kan spog met 'n kuslyn van asemrowende skoonheid wat toeriste uit alle dele van die wêreld lok? Dink aan die subtropiese Natal met sy wêreldberoemde getymere soos St. Lucia en Kosibaai en die koraalriwwe en goue strande van Maputuland. Of dink aan die ruwe suidkus met sy Tsitsikama Nasionale Park, Knysna met sy meer en geheimsinnige woude, Wildernis en verder wes die De Hoop Natuurreservaat. En dan die Weskus met Saldanha, Langebaan en Namakwaland waar die dorre halfwoestyn skielik in die lente in 'n lushof van blomtapyte verander. Suid-Afrika is waarlik geseën.

Maar sulke seëninge bring ook groot verantwoordelikhede mee. Dit wat aan ons geskenk is, moet met wysheid gebruik en bestuur word sodat die natuur se opbrengs volgehou mag bly - nie net vir ons nie, maar ook vir diegene wat ons moet volg. Die noodsaaklikheid vir wyse bestuur neem jaarliks toe soos Suid-Afrika se menslike bevolking en behoeftes aan ekonomiese ontwikkeling groei. In talle lande van die wêreld is die vernietigende gevolge van die kombinasie van meer mense met meer eise en moderne, tegnologies gebaseerde, dodelik doeltreffende ontginningsmetodes, duidelik te sien.

Is ons in Suid-Afrika in staat om uit daardie lesse te leer en om die druk wat op ons natuurbates geplaas word, beter te kan weerstaan?

Kom ons kyk eers na 'n paar positiewe aspekte wat hierdie vraag beïnvloed en dan na negatiewe aspekte. Sodoende behoort 'n mens 'n rasionele perspektief te kan vorm wat hopenlik sal bydra tot die ontwikkeling en toepassing van 'n beleid wat goeie kus-, maar ook algemene omgewingsbestuur, sal bevorder.

Daar bestaan geen twyfel nie dat daar oor die afgelope tien jaar ' $n$ realistieser bewustheid by staatsinstansies asook in die privaat sektor ontstaan het oor die ekonomiese en morele noodsaaklikheid om die omgewing en natuurlike hulpbronne van Suid-Afrika te beskerm. Dink aan die totstandkoming van 'n onafhanklike, statutêre liggaam, die Raad vir die Omgewing, in 1982 om die Minister van Omgewingsake van raad te bedien oor alle aspekte van omgewingsbestuur. Die Raad het staande komitees oor sake rakende die omgewing soos afval en besoedeling, die beboude omgewing, geraas, geïntegreerde omgewingsbestuur, land- en varswaterstelsels, kus- en mariene stelsels, sowel as die alomvattende take van omgewingsopvoeding en omgewingsreg. Pertinente verslae word oor al hierdie aspekte gepubliseer en aan die Kabinet beskikbaar gestel en daar is gereelde kontak tussen die Raad en die Minister en die Departement van Omgewingsake. Wat die kus betref, bestaan daar uitstekende samewerking tussen die Raad, die Departement van Omgewingsake en die Provinsies in die opstel van struktuurplanne en die verspreiding van inligting oor gesonde kusbestuur na alle plaaslike owerhede.

Die Staat se erns om die omgewing te beskerm word ook bewys deur die Staatspresident se opdrag aan die Presidentsraad om ondersoek in te stel na die huidige omgewingsbestuurstelsel in Suid-Afrika en hoe dit aangepas en verbeter kan word om te voldoen aan die vereistes van môre, van dié van die vinnig veranderende toestande in ons land.

Daarbenewens word dit al hoe duideliker dat departemente soos dié van Paaie probeer om onnodige omgewingskade te vermy, van Waterwese wat bekommerd is oor negatiewe ekologiese effekte van damme stroomaf en van Landbou wat rivieroewers wil beskerm en gronderosie en die afloop van skadelike landbouchemikalieë in strome en riviere wil voorkom.

Dat daar ernstige tekortkominge bestaan, is nie te betwyfel nie. Die veelvuldigheid van Departemente op alle regeringsvlakke wat met omgewingsbestuur te doen het, en gebrekkige skakeling tussen hulle, is van die ernstigstes. Daarbenewens is daar die verwarring wat geskep word deur te wye en dikwels onsamehangende omgewingswetgewing. Op plaaslike regeringsvlakke tree 'n gebrek aan insig na vore oor die noodsaaklikheid van 'n oorkoepelende en algehele kusbestuursbeleid vir die land, en al te dikwels die invloed van eie belang in besluitneming. En dan die grootste gebrek van almal: 'n toenemende tekort aan fondse binne staatsdepartemente wat vir omgewingsbestuur, insluitende die kus, verantwoordelik is. Ook die staat se bydrae vir broodnodige navorsing en opleiding van bekwame omgewingskundiges word al hoe meer teruggesnoei en instellings soos universiteite, tegnikons en die WNNR kwyn deur onvoldoende staatsondersteuning.

So belangrik soos behuising, skole, hospitale en die regstelling van onregverdighede van die verlede mag wees, is verwaarlosing van die omgewing 'n fatale fout. Hoe kan 'n gesonde ekonomie op 'n beskadigde omgewing gebou word en hoe moet toekomstige geslagte oorleef as sulke verwaarlosing nou toegelaat word?

Suid-Afrika kan baie dankbaar wees dat die sakesektor in hierdie kritieke stadium vir die omgewing in die bresse tree - al word hy dan ook dikwels van kapitalisme beskuldig. Die privaat sektor stel deur niestaatsomgewingsorganisasies soos die Suider-Afrikaanse Natuurstigting elke jaar miljoene rande beskikbaar vir geselekteerde natuurbewaringsen omgewingsopvoedingsprojekte. Meer nog, die privaat sektor het oor die afgelope drie jare trusts in die lewe geroep 
om dié taak doeltreffender te kan uitvoer. Die Suid-Afrikaanse Lugdiens se Afrika-natuurerfenistrust, MAZDA se Wildlewetrust en NEDBANK se Groen Trust is voorbeelde. En let op - die hulp is nie tot Suid-Afrika beperk nie, omdat ekologiese prosesse nie deur politieke grense beïnvloed word nie. Dit gaan oor die behoud van die Suider-Afrikaanse omgewing in sy geheel tot voordeel van al sy mense.

Wat hou die toekoms in? Met ons kus en mariene omgewing as vertrekpunt is in dié kort oorsig gekyk na omgewingsbewaring in die wyer sin. Die heel belangrikste oorweging moet sekerlik wees dat in al die woelinge oor die daarstelling van 'n nuwe bestel vir Suid-en Suider-Afrika, ons nie kan bekostig om voort te gaan om omgewingsoorwegings steeds ondergeskik te maak aan dié van politieke aard nie. Afrikalande ten noorde gee ' $n$ skrikwekkende beeld van die gevolge van sulke kortsigtigheid. Dit geld vanselfsprekend vir dic bestuur van ons kus en seebronne waarmee ons so ryklik geseën is. Maar dit geld ook vir die bestuur van ons land se omgewing in sy geheel, ons berge, riviere, grasvlaktes, woude en woestyne. Die omgewing behoort 'n oorkoepelende en verbindende vertrekpunt te wees vir die onderhandelingsproses wat hopelik binnekort sy aanvang sal neem.

Laat ons ons leiers - almal van hulle, ongeag herkoms en agtergrond - die wysheid toewens om die seën van Suider-Afrika se omgewing raak te sien, om ons bevolking se totale afhanklikheid daarvan te besef en om omgewingsoorwegings dus 'n kardinale vertrekpunt vir hulle onderhandelinge te maak.

ALLAN HEYDORN

\section{Suid-Afrika se seevisbronne - waar staan ons?}

Met 'n totale vangs van ongeveer $600000 \mathrm{t}$ vis ter waarde van nagenoeg Rl biljoen per jaar lewer SA se gesofistikeerde visbedryf direkte werksgeicentheid aan 25000 mense en maak dit 'n groot bydrae tot voorsiening in die land se groeiende proteienbehoeftes. Uitvoere van gesogte vissoorte soos veral kreef en perlemoen voorsien waardevolle buitelandse valuta, terwyl vismeel as dierebyvoedsel in die SA landbou onontbeerlik is.

Soos die roep van die visarend oor ons groot riviere is die krys van die seemeeu die simbool van die sosiokultuur van ons vissersgemeenskappe. Waar die koue, planktonryke Benguelastroom die Weskus noordwaarts omspoel, dáár hou die groot skoolvisse soos ansjovis, sardyn, maasbanker, stokvis en snoek in die voedingsryke waters van Antarktiese oorsprong. In die warm Agulhasstroom wat langs die Ooskus suidwaarts beweeg, hou veral die groot verskeidenheid hengelvisse soos kabeljou, vier-en-sewentig, mosselkraker en geelbek. In dieper water ver van die kus, en ook buite die RSA se 200-seemyljurisdiksiegebied, hou veral die groot trekvisse soos tuna, 'n gesogte vissoort veral vir die oosterse lande se onversadigbare behoefte aan sashimi (rouvis).

Sedert die inwerkingtreding van die RSA se eksklusiewe visseryesone van 200-seemyl op 1 November 1977 is vangste deur vreemde lande in ons waters stelselmatig ingekort en bedra hulle vangste tans minder as $3 \%$ van die opbrengs van alle kwotabeheerde vissoorte in RSA waters. Die Rereging het reeds aangedui dat alle vangste deur vreemde lande in ons waters binne die volgende twee jaar uitfaseer sal word. In teenstelling met 'n klaarblyklike populêre opvatting hou vangste deur vreemde bote geen bedreiging meer vir die RSA se visbronne in nie. Die welstand van ons visbronne is dus in ons eie hande.

Die huidige stand van SA se visbronne wissel na gelang van die aard van elke bron, die historiese bevistingspatroon en die toereikendheid van bronnavorsing. Die ansjovis is byvoorbeeld 'n oppervlakteskolende, kortlewende vissoort, en die suksesvolle oorlewing van sy eiers en larwes van jaar tot jaar het dus 'n onmiddellike en groot uitwerking op die grootte van die vangbare bron elke jaar. Daardie eiers en larwes is onderhewig aan wisselende omgewingsinvloede in die see soos byvoorbeeld temperatuur, seestrome, beskikbaarheid van voedsel en andere. Ongunstige omgewingsinvloede kan dus tot gevolg hê dat die opbrengsvermoë van die bron van jaar tot jaar aansienlik verskil, en inderdaad het die kwotas wat vir hierdie vissoort toegeken word, in die laaste aantal jare tussen 100000 t en 600000 t gewissel. Die kwota is vanjaar op 'n lae 150000 t vasgestel, wat die direkte gevolg is van ongunstige omgewingstoestande in die see (en gevolglike lae oorlewing van eiers en larwes) verlede jaar. 'n Verlaagde kwota vir ansjovis beteken dus nie dat die bron oorbevis is nie, maar wél dat die bron jaar na jaar en aan die hand van deurlopende en gesofistikeerde bronnavorsing, op sy korrekte dog wisselende volhoubare ontginningsvlak benut word.

In teenstelling met die ansjovis is die stokvis 'n langlewende bodemvis. Die oorlewing van sy eiers en jongvis is derhalwe minder onderhewig aan omgewingsinvloede, terwyl die effekte van wisselende jaarklasgroottes oor 'n groot bestek van jaarklasse in die vangbare bron versprei word. Die gevolg is dat die stokvisbron veel stabieler as byvoorbeeld ansjovis is en nie onderhewig is aan groot veranderinge in vangbare biomassa van jaar tot jaar nie. Op grond van deurlopende bronnavorsing is die jaarlikse kwotas die afgelope paar jaar in die omgewing van 'n redelike stabiele 140000 t vasgestel. Vóór 1978, toe vreemde lande nog onbeheerd langs die SA kus kon visvang, is die stokvisbron oorbevis. 'n Doelbewuste herstelstrategie, gegrond op intensiewe en deurlopende navorsing, het daartoe gelei dat die kwota in die vroeë tagtigerjare op so laag as 110000 t gestel is, en dat die bron sedertdien stelselmatig tot die huidige kwotavlak van 140000 t gegroei het. Inderdaad 'n suksesstorie in die besondere ingewikkelde veld van mariene bronnavorsing en -beheer. Daardie bestuurstrategie sal volgehou word totdat die bron sy berekende maksimum volhoubare opbrengsvlak van nagenoeg $160000 \mathrm{t}$ bereik.

Ietwat soortgelyk aan die stokvis, is die kreef 'n stadiggroeiende, langlewende bodemdier. Die jaarlikse kwota was die afgelope aantal jare dan ook redelik stabiel in die omgewing van $4000 \mathrm{t}$, wat beskou kan word as die langtermyn volhoubare opbrengsvlak van daardie bron. Aanpassings in die kwotavlak word jaarliks, weer eens gegrond op intensiewe navorsing, opwaarts of afwaarts gemaak na gelang die bronbiomassa vanweë natuurlike corsake toeneem of afneem. Soos in die geval van ansjovis en stokvis beteken 'n kwotaverlaging nie noodwendig dat die bron oorbevis is nie, maar is dit bloot 'n wetenskaplik gefundeerde aanpassing 
by jaarlikswisselende bronsterktes.

Anders as in die landbou waar produksieperke op grond van vraag-en-aanbod oorwegings gestel word, word beperkings op visvangste (kwotas) suiwer op grond van die wisselende jaarlikse natuurlike opbrengsvermoë van elke bron ingestel.

Die kreefbedryf staar hierdie jaar, en na verwagting minstens ook volgende jaar, 'n ernstige krisis in die gesig. Die kreefbron word in essensie bestuur by wyse van die bepaling van die massa kreef wat jaarliks die minimum wettige maatgrootte van $89 \mathrm{~mm}$ oorskry en sodoende vir die bedryf vangbaar raak. Die normale groeikoers van 5-6 mm karapaksdoplengte per jaar verseker dat genoegsame kreef vanuit die moederbron die minimum wettige grootteperk oorskry. Hierdie jaar, egter, het die kreef slegs ongeveer $1 \mathrm{~mm}$ gegroei as gevolg van ongunstige omgewingstoestande in die see; gevolglik het min kreef die wettige maatgrootte bereik en was relatief min kreef ( $\pm 25 \%$ minder as die kwota) vir die bedryf vangbaar. Weer eens dui hierdie situasie nie op oorbevisting nie, maar dit is die gevolg van natuurlike oorsake; die kwota vir volgende jaar sal dienooreenkomstig afwaarts aangepas word.

In teenstelling met die sterk navorsingsbasis vir die bestuur van die stokvis, ansjovis, kreef en perlemoenbronne is die navorsingsbasis vir veral die groot getalle lynvissoorte ontoereikend. Dit is van deurslaggewende belang dat voldoende befondsing en kundige mannekrag vir navorsing oor ons seevisbronne beskikbaar gestel word om daardie bronne teen oorbevisting te vrywaar.

Soos kortliks aan die hand van enkele voorbeelde hier bo aangedui, is die meeste belangrike Suid-Afrikaanse seevisbronne (met uitsondering van hoofsaaklik sardyn wat in 'n herstelfase ná vroeëre oorbevisting is) nie oorbevis nie, maar etlikes is tans in 'n fase van lae opbrengs (siklies ?) as gevolg van ongunstige omgewingstoestande in die see. Deurlopende navorsing en ' $n$ doelgerigte bronbestuursbeleid gemik op volhoubare opbrengs sal verseker dat daardie waardevolle bronne 'n voortgesette nasionale bate bly.

L. BOTHA 